\title{
Anti-diabetic effect of betulinic acid on streptozotocin- nicotinamide induced diabetic male mouse model
}

\author{
Golshan Arzani Birgani ${ }^{1}$, Akram Ahangarpour ${ }^{2 *}$, Layasadat Khorsandi ${ }^{3}$, Hadi Fathi Moghaddam² \\ ${ }^{1}$ Department of Physiology, Student Research Committee, Ahvaz Jundishapur University of Medical Science, Ahvaz, Iran, \\ ${ }^{2}$ Department of Physiology, Physiology Research Center, School of Medicine, Ahvaz Jundishapur University of Medical \\ Sciences, Ahvaz, Iran, ${ }^{3}$ Department of Anatomical Sciences, School of Medicine, Cell \& Molecular Research Center, Ahvaz \\ Jundishapur University of Medical Sciences, Ahvaz, Iran
}

\begin{abstract}
Diabetes is a metabolic disease caused by abnormal insulin secretion or action. In the present study, the effects of betulinic acid (BA, a triterpene) are evaluated on glucose, $\alpha$-amylase and plasma insulin levels, insulin resistance and the histopathology of pancreatic islets in streptozotocin-nicotinamide (STZNA) diabetic mice. Seventy adult male NMRI mice were randomly divided into seven groups: control, sham, diabetic, diabetic treated with BA $(10,20$ and $40 \mathrm{mg} / \mathrm{kg})$ and diabetic treated with metformin $(200 \mathrm{mg} / \mathrm{kg})$. Diabetes was induced in mice by intraperitoneal injection of streptozotocin $50 \mathrm{mg} / \mathrm{kg}$ after a dose of nicotinamide $120 \mathrm{mg} / \mathrm{kg}$. Two weeks after treatment with BA, blood samples were collected for measuring glucose, $\alpha$-amylase and insulin levels, and the pancreas was isolated for histopathology evaluation. Diabetes reduced the number and diameter of pancreatic islets, and increased $\alpha$-amylase and insulin resistance. BA treatment reduced blood glucose, $\alpha$-amylase and improved insulin sensitivity as well as pancreas histopathology. In addition, BA showed stronger effects on the pancreatic histology and insulin resistance compared to the metformin group.
\end{abstract}

Keywords: Betulinic acid. Diabetes. Mouse. Streptozotocin-nicotinamide.

\section{INTRODUCTION}

Diabetes mellitus is a global health problem. Insulin deficiency leads to failure of glucose consumption in diabetes mellitus (DM) and breakdown of lipids and proteins (Mousavi et al., 2011). This disease causes cardiovascular disease, retinopathy, neuropathy and other long-term complications in uncontrolled conditions (Ahangarpour et al., 2016a).

In experimental studies, streptozotocin (STZ) nicotinamide (NA) diabetic mice are one of the models that can induce mild diabetes (Tahara, MatsuyamaYokono, Shibasaki, 2011). STZ causes pancreatic $\beta$-cell damage with transport into $\beta$-cells via the glucose transporter (Glut2) and causes DNA damage; in contrast, NA partially protects against the harmful effects of

Correspondence: A. Ahangarpour. Department of Physiology, School of Medicine, Physiology Research Center, Ahvaz Jundishapur University of Medical Sciences, Ahvaz, Iran. Tel: 00989166080817. Fax: 0098-613-333-2036. E-mail: akramahangarpour@gmail.com
STZ (Szkudelski, 2012). Nicotinamide prevents the diabetogenic effect of STZ via the NO product and prevents apoptosis, as well as having a protective effect in the first phase of insulin release (Alenzi, 2009). Rats treated with STZ and NA manifest symptoms of type 2 diabetes, while animals with STZ-induced type 1 diabetes. $\beta$-cells in these rats were partly damaged, therefore insulin secretion was preserved in response to glucose and some other stimulants (Szkudelski, 2012). Although several therapeutic agents have been used for diabetes mellitus treatment in recent decades, most therapeutic goals have remained unmet. So, a new approach is required for treatment of type 2 diabetes. Studies have shown that to treat and manage type 2 diabetes and its complications, several long-used herbal medicines appear to be effective (Jeong et al., 2012); for example, triterpenoids, which are a large group of compounds present in many plants (Silva et al., 2016). These compounds divide into lupane, oleonane and ursane groups (Jager et al., 2009). 3 $\beta$-Hydroxylup-20(29)-en-28-oic acid, betulinic acid (BA) is a 
plant-derived pentacyclic triterpenoid of the lupane-type triterpenes. Betulinic acid can inhibit different enzymes related to carbohydrate/lipid absorption and metabolism, such as $\alpha$-amylase (Yoshizumi et al., 2006), protein tyrosine phosphatase1B (Zhang et al., 2008), glycogen phosphorylase, and diacylglycerol acetyltransferase $\alpha$-glucosidase (Zareen et al., 2008). Also, BA can increase insulin and leptin secretion (Melo et al., 2009). An in vitro incubation of BA in human aortic smooth muscle cell (HASMC) showed that BA can decrease the intracellular reactive oxygen species (ROS), and suppress the nuclear translocation and phosphorylation of IRB- $a_{\alpha}$ under high glucose conditions; therefore, BA can inhibit diabetic vascular disease (Yoon et al., 2010). BA has a preventive effect on diabetic nephropathy during diabetic situations (Ahangarpour et al., 2016b). In contrast, administration of BA in STZ-NA diabetic treated mice can induce a worse outcome in the male reproductive system (Ahangarpour et al., 2016c). BA can be useful for treatment and prevention of early atherosclerosis (Yoon et al., 2017). In obese rats with a high fat diet, BA inhibited TGR5 (a G protein-coupled receptor expressed in brown adipose tissues and muscles), and furthermore reduced body weight, abdominal fat accumulation, blood glucose, plasma triglyceride (TG) and total cholesterol (Melo et al., 2009). Hence, there is not enough evidence about the efficiency of the antidiabetic property of BA. This study was conducted to determine the effect of BA on $\alpha$-amylase, and insulin levels, hyperglycemia and histological abnormalities of the pancreas in streptozotocin-nicotinamide induced diabetic mice, due to the lack of evidence on the efficiency of the antidiabetic properties of BA.

\section{MATERIAL AND METHODS}

\section{Materials}

Streptozotocin, nicotinamide, betulinic acid and metformin were purchased from Sigma- Aldrich CO (St. Louis, MO, USA).

\section{Animals}

Adult male Naval Medical Research Institute (NMRI) mice ( $\mathrm{n}=70,5$ weeks old, 25-35gr) were obtained from the Ahvaz Jundishapur University of Medical Sciences Animal Care Center (IRAN).

Animals were housed under a controlled temperature of $25^{\circ} \mathrm{C}$ and $12 \mathrm{~h}$ light $-12 \mathrm{~h}$ dark cycle. All mice were allowed ad libitum access to food and water.

\section{Experimental design}

The mice were randomly divided into seven groups of ten animals: Controls were administered with a normal diet, Sham (received $0.1 \mathrm{~mL}$ normal saline i.p. daily for 2 weeks), Type 2 diabetic as negative control (received STZ $50 \mathrm{mg} / \mathrm{kg}$ in $0.1 \mathrm{~mL}$ citrate buffer $\mathrm{pH} 4.5,15 \mathrm{~min}$ after a single dose of NA $120 \mathrm{mg} / \mathrm{kg}$ in $0.1 \mathrm{~mL}$ normal saline, i.p.), Type 2 diabetic + BA, received 10, 20 and $40 \mathrm{mg} /$ $\mathrm{kg}$, in $0.3 \mathrm{~mL}$ normal saline (Xie et al., 2017) daily gavage for 2 weeks after induction of type 2 diabetes, and Type 2 diabetic + metformin as positive control, received $200 \mathrm{mg} /$ $\mathrm{kg}$ in $0.3 \mathrm{~mL}$ normal saline, daily gavage for 2 weeks after induction of type 2 diabetes(Ahangarpour et al., 2016b).

\section{Induction of animal model of type 2 diabetes}

Diabetes was induced in overnight fasted mice, according to the method of Lee et al. (2010). Diabetes was induced in mice by intraperitoneal injection of streptozotocin $50 \mathrm{mg} / \mathrm{kg}$ after a dose of nicotinamide 120 $\mathrm{mg} / \mathrm{kg}$. After 72 hours of the STZ-NA injection, blood glucose levels were determined and mice with blood glucose levels higher than $200 \mathrm{mg} / \mathrm{dl}$ were used in the following experiments.

\section{Biochemical assessment}

Blood glucose levels were determined by a glucometer (Elegance CT-X10, convergent technologies, Germany) and biochemical assay kits (Pars Azmoon, Iran), with a sensitivity of $0.1 \mathrm{mg} / \mathrm{dl}$. Plasma $\alpha$-amylase concentration was measured by a commercially available kit (Pars-Azmoon Co., Iran) using an Autoanalyzer device (BT3000, Italy), with a sensitivity of 1 IU/L. The plasma insulin level was evaluated by using ELISA assay kits (Monobind Inc, USA). The assay sensitivity was found to be $0.182 \mu \mathrm{IU} / \mathrm{ml}$, while the inter-assay coefficient of variation $(\mathrm{CV})$ was $7.2 \%$, and the intra-assay $\mathrm{CV}$ was $4.3 \%$. A homeostatic model assessment of insulin resistance (HOMA-IR), homeostatic model assessment of pancreatic $\beta$-cell function (HOMA- $\beta$ ), quantitative insulin sensitivity check index (QUICKI) and insulin disposition index (DI) were calculated by using the following formulae:

HOMA-IR: fasting blood glucose $(\mathrm{FBS})(\mathrm{mg} / \mathrm{dL}) \times$ insulin $(\mu \mathrm{IU} / \mathrm{mL}) / 405$

HOMA- $\beta$ : $20 \times$ insulin $(\mu \mathrm{IU} / \mathrm{mL}) /(\mathrm{FBS}(\mathrm{mMol} / \mathrm{L})-3.5)$ QUICKI: 1/ $(\log$ FBS $(\mathrm{mg} / \mathrm{dL})+\log$ insulin $(\mu \mathrm{IU} / \mathrm{mL}))$ (Ma et al., 2014)

DI: HOMA- $\beta /$ HOMA-IR assayed (Li et al., 2014) 


\section{Histological assessment}

The pancreas of the mice were removed immediately and fixed in $10 \%$ formalin solution. Then, tissues were dehydrated in graded alcohol concentrations and embedded in paraffin. Sections of 4-6 $\mu \mathrm{m}$ were prepared and stained with hematoxylin \& eosin (H\&E). Six H\&E stained slides per animal were examined for assessment of histological changes such as number and diameter of islets, which were determined by using Motic images plus 2.0 image analysis software. Finally, a blind method was used for slide reading (Khorsandi, Nejad-Dehbashi, 2013).

\section{Statistical analysis}

Data are expressed as means \pm S.E.M. Statistical comparison between different groups was performed using one-way analysis of variance (ANOVA) followed by a post-hoc Tukey HSD test, with $\mathrm{p}<0.05$ being regarded as significant.

\section{RESULTS AND DISCUSSION}

\section{Effects of STZ-NA, metformin and BA treatment on blood glucose and $\alpha$-amylase levels in mice}

As shown in Table I, injection of STZ-NA raised blood glucose (Table I) and $\alpha$-amylase (Figure 1) compared to saline groups $(\mathrm{p}<0.001$ and $\mathrm{p}<0.05$, respectively). However, no significant change $(\mathrm{p}>0.05)$ occurred in body weight.

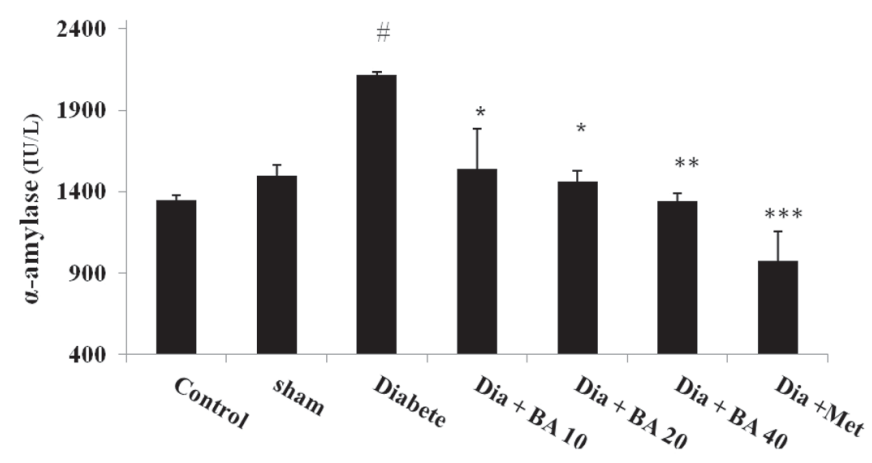

FIGURE 1 - Effect of different doses of betulinic acid on $\alpha$-amylase in STZ-NA diabetic mice. Data expressed as mean \pm SEM. ${ }^{*} \mathrm{p}<0.05,{ }^{*} \mathrm{p}<0.01$ and, $* * * \mathrm{p}<0.001$ as compared with diabetic group; $\# \mathrm{p}<0.05$ as compared with control and sham groups, $\mathrm{n}=10$ (ANOVA and Tukey's test).

The mean of fasting plasma glucose (Table I, $\mathrm{p}<0.001$ ) and $\alpha$-amylase concentration (Figure 1 , $\mathrm{p}<0.05)$ decreased in BA- and metformin-treated animals compared to the diabetic group. The metformin administration showed no significant change compared to the BA groups. Therefore, betulinic acid may act through a similar mechanism to that of metformin.

TABLE I - Effect of different doses of betulinic acid on fasting glucose, insulin level, insulin biomarkers and body weight in STZNA diabetic mice

\begin{tabular}{|c|c|c|c|c|c|c|c|}
\hline $\begin{array}{l}\text { Factors } \\
\text { Groups }\end{array}$ & $\begin{array}{l}\text { Fasting } \\
\text { glucose } \\
(\mathrm{mg} / \mathrm{dl})\end{array}$ & $\begin{array}{l}\text { Insulin } \\
(\mu \mathrm{IU} / \mathrm{ml})\end{array}$ & HOMA-IR & НОМА- $\beta$ & QUICKI & DI & $\begin{array}{c}\text { Body weight } \\
\text { (g) }\end{array}$ \\
\hline Sham & $86.7 \pm 3.6$ & $15.5 \pm 2.3$ & $3.4 \pm 0.9$ & $247.2 \pm 36.6$ & $0.322 \pm 0.007$ & $5.2 \pm 0.7$ & $34.6 \pm 1.5$ \\
\hline Diabetes & $\begin{array}{c}152.8 \pm 10.8 \\
\# \# \#\end{array}$ & $14.7 \pm 1.9$ & $\begin{array}{c}5.5 \pm 0.7 \\
\# \# \#\end{array}$ & $\begin{array}{c}62.8 \pm 9.2 \\
\#\end{array}$ & $\begin{array}{c}0.300 \pm 0.004 \\
\#\end{array}$ & $\begin{array}{c}2.5 \pm 0.2 \\
\#\end{array}$ & $35.7 \pm 1.2$ \\
\hline Diabetes $+20 \mathrm{mg}$ & $\begin{array}{c}79.8 \pm 3.43 \\
* * *\end{array}$ & $14.1 \pm 1.5$ & $\begin{array}{l}2.8 \pm 0.4 \\
* * *\end{array}$ & $\begin{array}{c}356.7 \pm 68.2 \\
* * *\end{array}$ & $\begin{array}{c}0.330 \pm 0.006 \\
* * *\end{array}$ & $\begin{array}{l}6.9 \pm 1.4 \\
* * *\end{array}$ & $34.5 \pm 1.7$ \\
\hline Diabetes $+40 \mathrm{mg}$ & $\begin{array}{c}79.2 \pm 2.8 \\
* * *\end{array}$ & $12.7 \pm 0.6$ & $\begin{array}{l}2.5 \pm 0.1 \\
* * * \$\end{array}$ & $\begin{array}{c}343.9 \pm 72.1 \\
* * *\end{array}$ & $\begin{array}{c}0.333 \pm 0.002 \\
* * *\end{array}$ & $\begin{array}{c}6.6 \pm 0.7 \\
* *\end{array}$ & $35.2 \pm 1.7$ \\
\hline
\end{tabular}

Data expressed as mean \pm SEM. ${ }^{*} \mathrm{p}<0.05,{ }^{* *} \mathrm{p}<0.01$ and, ${ }^{* * *} \mathrm{p}<0.001$ as compared with diabetic group; ${ }^{\#} \mathrm{p}<0.05$ and, ${ }^{\# \# \#} \mathrm{p}<0.001$ as compared with control and sham groups, $\$ \mathrm{p}<0.05$ as compared with metformin group, $\mathrm{n}=10$ (ANOVA and Tukey’s test). QUICKI= quantitative insulin sensitivity check index, DI = insulin disposition index. 
The type 2 diabetogenic effect of STZ-NA was previously reported (Lee et al., 2010). STZ-induced hyperglycemia can destroy pancreatic beta cells by induction of oxidative stress (Singh et al., 2007). Therefore, NA as an antioxidant can invert this effect and protect beta cells against the oxidant effect of STZ (Alenzi et al., 2009). In this study, it was shown that BA can reduce STZ-NA induced complications. Consistent with the present study, Lee et al. (2010) showed that ursolic acid (a triterpenoid of the ursane group) improved blood glucose levels in STZ-NA induced diabetic mice. They suggested that this effect may be due to inhibition of hepatic glucose production. Also, Chia et al. (2012) showed that treatment by glycyrrhetinic acid, the aglycone derivative of glycyrrhizinic acid, led to blood glucose levels being decreased in STZ-diabetic rats. Consistent with the present study, earlier studies have reported the effects of betulinic acid on high fat diet-induced diabetic mice (Kim et al., 2014) and by oleanolic acid in STZ-diabetic mice (Gao et al., 2007). In agreement with the present study, isolated betulinic acid from S. cumini decreased plasma levels of $\alpha$-amylase (Karthic et al., 2008). Because enzymes catalyze the most important biochemical pathways, enzyme inhibitors could be a potential target in many areas of disease control and treatment. In this aspect, amylase inhibitors are of particular importance (Kim, Nho, 2004).

Metformin is a biguanide antidiabetic medication that lowers blood glucose through inhibition of gluconeogenesis and increases utilization of glucose in liver, muscle and intestine (Hundal et al., 2000) and shows efficacy in reducing type 2 diabetes in mice (Lee et al., 2010). Therefore, we used metformin to compare its effects with BA treated groups, as a positive control. In this study, administration of metformin for 2 weeks in STZ-NA induced diabetic mice decreased blood glucose and $\alpha$-amylase. The favorable effects exerted by BA on the level of blood glucose and $\alpha$-amylase were similar to metformin treatment. The combination therapy with metformin and oleanolic acid was shown to have synergistic effects by improving glucose homeostasis in type 2 diabetes (Wang et al., 2015).

\section{Effects of STZ-NA, metformin and BA treatment on insulin and insulin sensitivity biomarkers in mice}

Plasma insulin levels had no significant difference between BA groups compared to the diabetic control group. In addition, there was no significant difference between metformin groups compared to BA groups ( $>0.05$, Table I).
Insulin resistance was assessed by using the HOMA-IR and QUICKI indexes. Insulin sensitivity was reduced, as revealed by increased HOMA-IR $(\mathrm{p}<0.001)$ concomitantly with reduction of HOMA- $\beta$ and QUICKI values $(\mathrm{p}<0.05)$, observed in the diabetic control group. After 2 weeks of treatment, BA, diabetic + BA 10, 20 and $40 \mathrm{mg} / \mathrm{kg}$ groups possessed significantly increased HOMA- $\beta$, QUICKI and DI values compared to the diabetic control group $(p<0.01, p<0.001$ and $p<0.001$, respectively). With the metformin group, this biomarker did not significantly alter compared to BA groups (Table I). HOMA-IR, HOMA- $\beta$, QUICKI and DI were calculated to investigate the health of insulin-producing cells and function of insulin. HOMA-IR was used to quantify insulin resistance and HOMA- $\beta$ was used to quantify $\beta$-cell function. HOMA- $\beta$ and QUICKI correlate with HOMA-IR (Dube et al., 2013). The results show that treatment with BA in STZ-NA diabetic mice decreased HOMA-IR compared with the control group. Also, Chia et al. (2012) showed that treatment with glycyrrhizinic acid (a triterpenoid of the ursane group) decreased HOMA-IR due to a decrease in the gluconeogenesis ratelimiting enzymes. Consistent with our study, treatment with betulin improved insulin sensitivity (Tang et al., 2011). However, in the administration of BA as an anti-diabetic agent, side effects such as those on the reproductive system should be considered (Ahangarpour et al., 2016c).

Administration of metformin for 2 weeks in STZNA induced diabetic mice decreased insulin resistance and increased other insulin biomarkers. The favorable effects exerted by BA on the insulin biomarkers are similar to those associated with metformin treatment. The combination therapy with metformin and oleanolic acid was shown to have synergistic effects by improving insulin production in type 2 diabetes (Wang et al., 2015).

\section{Effects of STZ-NA, metformin and BA on pancreas histology}

The exocrine part of the pancreas in all control and treatment groups showed a normal appearance, and all pancreas sections revealed a normal appearance in control and sham groups. The islet numbers were reduced dramatically in the diabetic group $(\mathrm{p}<0.001)$; BA at different doses could significantly reverse the number of islets in a dose-dependent manner. The diameter of islets was reduced significantly in diabetic animals $(p<0.001)$, but increased in BA treatment groups in comparison to positive control groups. This effect of BA (from 10 to $40 \mathrm{mg}$ ) was also dose dependent, with $40 \mathrm{mg} / \mathrm{kg}$ BA being 
found to be more effective on the increase of islet diameter (Table II and Figure 2).

In type 2 diabetes, beta-cell function and mass is lost progressively. The histological assessment of diabetic treated groups indicates an increase in the diameters and number of pancreatic islets and $\beta$-cell function in the group which received BA treatments, which may be illustrative of pancreatic islet regeneration. In addition, betulinic acid showed stronger effects on the pancreatic histology compared to the metformin group. This result may relate to the antioxidant effect of BA. In agreement with this study, glycyrhizinic acid can increase the diameter and count of pancreatic islets (Sen, Roy, Chakraborti, 2011). Also, an increase in $\beta$-cell function has been reported for other triterpenes (Jang et al., 2009).

\section{CONCLUSION}

This study demonstrated that BA can effectively decrease blood glucose, $\alpha$-amylase levels and increase numbers and diameters of islets in animal type 2 diabetes. Although insulin levels did not change, insulin resistance decreased in BA-treated mice. In the other words, betulinic acid has hypoglycemic properties, which could be explained by improved insulin resistance and/or pancreatic islet regenerative effects of betulinic acid in STZ-NA diabetic mice. The dose-dependent effect of BA is observed only in the pancreas histology, with a more pronounced effect exerted by the highest concentration of BA tested. A higher concentration is likely required to produce better histological changes. Further clinical

TABLE II - Effect of different doses of betulinic acid on pancreatic islets diameter and number in STZ-NA diabetic mice

\begin{tabular}{lccccccc}
\hline $\begin{array}{l}\text { Factors } \\
\text { Groups }\end{array}$ & Control & Sham & Diabetes & $\begin{array}{c}\text { Diabetes }+ \\
\mathbf{1 0 m g}\end{array}$ & $\begin{array}{c}\text { Diabetes }+ \\
\mathbf{2 0 m g}\end{array}$ & $\begin{array}{c}\text { Diabetes }+ \\
\text { 40mg }\end{array}$ & Metformin \\
\hline Diameter $(\mu \mathrm{m})$ & $118.3 \pm 9.4$ & $106.6 \pm 5.9$ & $\begin{array}{c}76.9 \pm 6.7 \\
\# \#\end{array}$ & $94.6 \pm 6.2$ & $98.3 \pm 5.8$ & $127.0 \pm 4.9$ & $106.7 \pm 8.6$ \\
& & & & & $* * * \$ \$ \$$ & $*$ \\
Number & $5.0 \pm 0.0$ & $4.3 \pm 0.3$ & $2.0 \pm 0.0$ & $6.0 \pm 0.0$ & $6.3 \pm 0.3$ & $7.3 \pm 0.3$ & $4.3 \pm 0.9$ \\
& & & $\# \# \#$ & $* * *$ & $* * *$ & $* * * \$ S$ & $* * *$ \\
\hline
\end{tabular}

Data are expressed as mean \pm SEM. " $p<0.05$, and ${ }^{* * * *} \mathrm{p}<0.001$ as compared with diabetic group; $\# \# \mathrm{p}<0.01$ and, ${ }^{\# \# \# "} \mathrm{p}<0.001$ as compared with control and sham groups, $\$ \$ \$ p<0.001$ as compared with metformin group, $n=10$ (ANOVA and Tukey’s test).
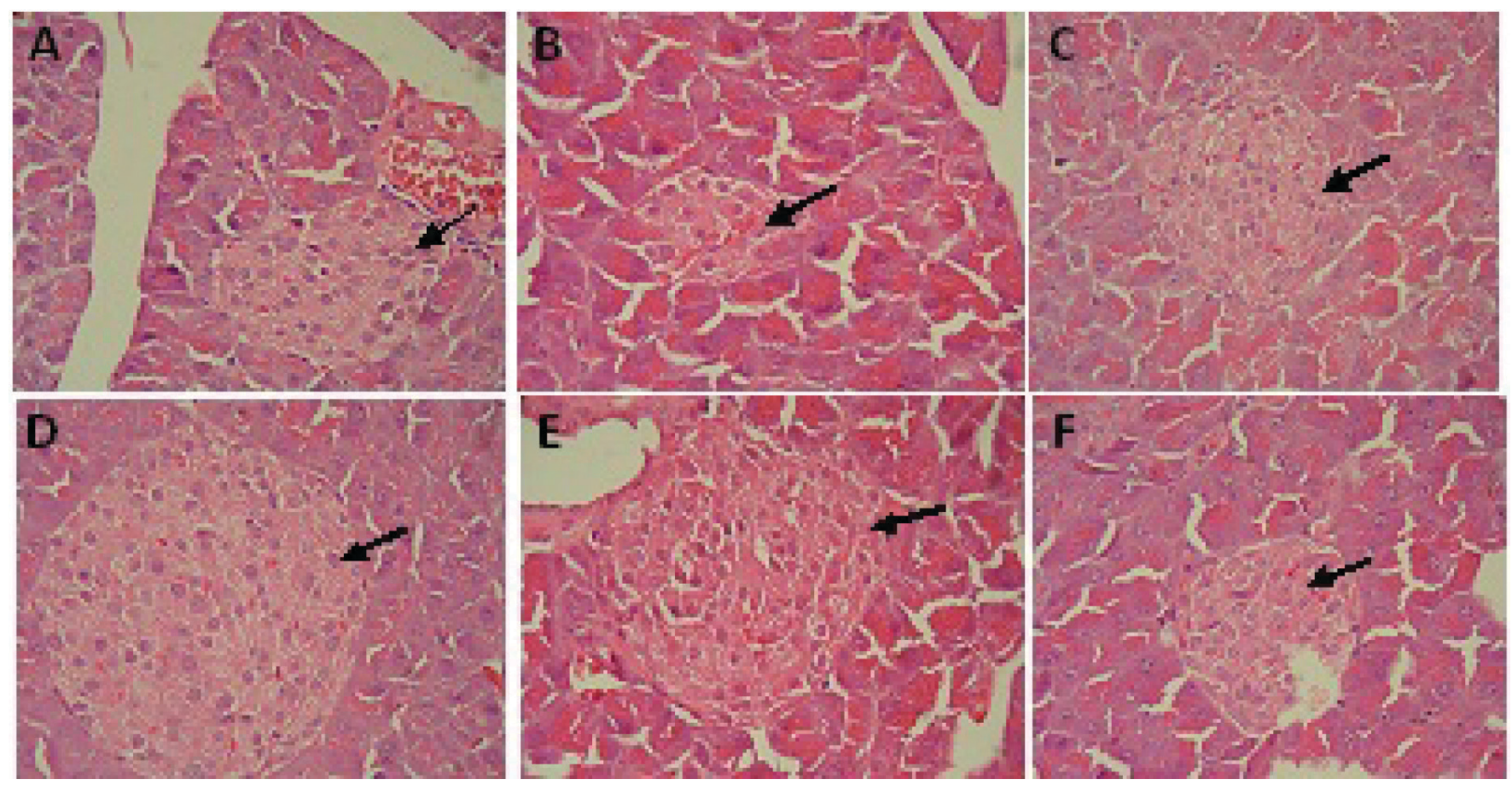

FIGURE 2 - Effect of different doses of betulinic acid on islets and pancreas histological analysis in STZ-NA diabetic mice. A: Control, B: Diabetic, C: Diabetic+BA10mg, D: Diabetic+BA20mg, E: Diabetic+BA40mg, F: Metformin. (H\&E stain $\times$ 400). Arrow: Islets of Langerhans. 
studies are required to support this proposal and also to establish the beneficial effects of betulinic acid on blood glucose levels and insulin resistance.

\section{ACKNOWLEDGEMENTS}

This article is Golshan Arzani Birgani's M.Sc. thesis and supported financially by the Physiology Research Center of Ahvaz Jundishapur Medical Sciences University, Ahvaz, Iran (Grant No. APRC-9422).

\section{CONFLICT OF INTEREST}

There is no conflict of interest.

\section{REFERENCES}

Ahangarpour A, Ali-Akbari FR, Mohaghegh SM, Asadinia E. Effects of Arctium lappa aqueous extract on lipid profile and hepatic enzyme levels of sucrose-induced metabolic syndrome in female rats. Brazil J Pharm Sci. 2016a;52(3):425-31.

Ahangarpour A, Oroojan AA, Khorsandi L, Shabani R, Mojaddami S. Preventive effects of betulinic acid on streptozotocin nicotinamide induced diabetic nephropathy in male mouse. J Nephropathol. 2016b;5(4):128.

Ahangarpour A, Oroojan AA, Khorsandi L, Arzani G, Afshari G. Effects of Betulinic Acid on the Male Reproductive System of a Streptozotocin-Nicotinamide-Induced Diabetic Mouse Model. World J Men's Health. 2016c;34(3):209-16.

Alenzi FQ. Effect of nicotinamide on experimental induced diabetes. Iran J Allergy Asthma Immunol. 2009;8(1):11-8

Chia YY, Liong SY, Ton SH, Kadir KB. Amelioration of glucose homeostasis by glycyrrhizic acid through gluconeogenesis ratelimiting enzymes. Eur J Pharmacol. 2012;677(1-3):197-202.

Dube S, Errazuriz I, Cobelli C, Basu R, Basu A. Assessment of insulin action on carbohydrate metabolism: physiological and non-physiological methods. Diabetic Med. 2013;30(6):664-70.

Gao D, Li Q, Li Y, Liu Z, Liu Z, Fan Y, et al. Antidiabetic potential of oleanolic acid from Ligustrum lucidum Ait. This article is one of a selection of papers published in this special issue (part 2 of 2) on the Safety and Efficacy of Natural Health Products. Can J Physiol Pharmacol. 2007;85(11):1076-83.
Hundal RS, Krssak M, Dufour S, Laurent D, Lebon V, Chandramouli V, et al. Mechanism by which metformin reduces glucose production in type 2 diabetes. Diabetes. 2000;49(12):2063-9.

Jager S, Trojan H, Kopp T, Laszczyk MN and Scheffler A. Pentacyclic triterpene distri-bution in various plants rich sources for a new group of multi-potent plantextracts. Molecules. 2009;14(6):2016-31.

Jang SM, Yee ST, Choi J, Choi MS, Do GM, Jeon SM, et al. Ursolic acid enhances the cellular immune system and pancreatic beta-cell function in streptozotocin-induced diabetic mice fed a high-fat diet. Int Immunopharmacol. 2009;9(1):113-9.

Jeong TY, Park BK, Cho JH, Kim YI, Ahn YC, Son CG. A prospective study on the safety of herbal medicines, used alone or with conventional medicines. J Ethnopharmacol. 2012;143(3):884-8.

Karthic K, Kirthiram KS, Sadasivam S, Thayumanavan B. Identification of $\alpha$-amylase inhibitors from Syzygium cumini Linn Seeds. Indian J Exp Biol. 2008;46(9):677-80.

Kim JS, Yan QH, Ju JK, Yeon KD, Woon KG, Kyung JH, et al. Beneficial effect of betulinic acid on hyperglycemia via suppression of hepatic glucose production. J Agric Food Chem. 2014;62(2):434-42.

Kim SD, Nho HJ. Isolation and characterization of _-Glucosidase inhibitor from the fungus Ganoderma lucidum. J Microbiol. 2004;42(3):223-7.

Khorsandi L, Nejad-Dehbashi F. Exendin-4 effects on islet volume and number in mouse pancreas. Braz J Pharm Sci. 2013;49(4):745-52.

Lee J, Yee ST, Kim JJ, Choi MS, Kwon EY, Seo KI, Lee MK. Ursolic acid ameliorates thymic atrophy and hyperglycemia in streptozotocin-nicotinamide-induced diabetic mice. Chem Biol Interact. 2010;188(3):635-42.

Li B, Lin W, Lin N, Dong X and Liu L. Study of the correlation between serum ferritin levels and the aggregation of metabolic disorders in non-diabetic elderly patients. Exp Ther Med. 2014;7(6):1671-6.

Ma Y, Wang Y, Huang Q, Ren Q, Chen S, Zhang A, et al. Impaired $\beta$ cell function in chinese newly diagnosed Type 2 Diabetes Mellitus with hyperlipidemia. J Diabetes Res. 2014;2014:ID493039. 
Melo CL, Queiroz MG, Arruda Filho AC, Rodregoes AM, De Sousa DF, Almedia JG, et al. Betulinic acid, a natural pentacyclic triterpenoid, prevents abdominal fat accumulation in mice fed a high-fat diet. J Agric Food Chem. 2009;57(19):8776-81.

Mousavi SE, Shahriari A, Ahangarpour A, Vatanpour H, Jolodar A. Effects of teucrium polium ethylacetate extract on serum, liver and muscle triglyceride content of sucrose-induced insulin resistance in Rat. Iran J Pharm Res. 2011;11(1):347-55.

Sen S, Roy M, Chakraborti AS. Ameliorative effects of glycyrrhizin on streptozotocin-induced diabetes in rats. J Pharm Pharmacol. 2011;63(2):287-96.

Silva FS, Oliveira PJ, Duarte MF. Oleanolic, Ursolic, and betulinic acids as food supplements or pharmaceutical agents for Type 2 Diabetes: promise or illusion? J Agric Food Chem. 2016;64(15):2991-3008.

Singh SK, Kesari AN, Gupta RK, Jaiswal D, Watal G. Assessment of antidiabetic potential of Cynodon dactylon extract in streptozotocin diabetic rats. J Ethnopharmacol. 2007;114(2):174-9.

Szkudelski T. Streptozotocin-nicotinamide-induced diabetes in the rat Characteristics of the experimental model. Exp Biol Med. 2012;237(5):481-90.

Tahara A, Matsuyama-Yokono A, Shibasaki M. Effects of antidiabetic drugs in high-fat diet and streptozotocinnicotinamide-induced type 2 diabetic mice. Eur J Pharmacol. 2011;655(1):108-16.

Tang JJ, Li JG, Qi W, Qiu WW, Li PS, Li BL, et al. Inhibition of SREBP by a small molecule, betulin, improves hyperlipidemia and insulin resistance and reduces atherosclerotic plaques. Cell Metab. 2011;13(1):44-56.
Wang X, Chen Y, Abdelkader D, Hassan W, Sun H, Liu J. Combination therapy with oleanolic acid and metformin as a synergistic treatment for diabetes. J Diabetes Res. 2015;2015:ID973287.

Xie R, Zhang H, Wang XZ, Yang XZ, Wu SN, Wang HG et al. The protective effect of betulinic acid (BA) diabetic nephropathy on streptozotocin (STZ)-induced diabetic rats. Food Funct. 2017;8(1):299-306.

Yoon JJ, Lee YJ, Han BH, Choi ES, Kho MC, Park JH, et al. Protective effect of betulinic acid on early atherosclerosis in diabetic apolipoprotein-E gene knockout mice. Eur J Pharmacol. 2017;796:224-32.

Yoon JJ, Lee YJ, Kim JS, Kang DG, Lee HS. Betulinic acid inhibits high glucose induced vascular smooth muscle cells proliferation and migration. J Cell Biochem. 2010;111(6):150111.

Yoshizumi K, Hirano K, Ando H, Hirai Y, Ida Y, Tsuji T, et al. Lupane-type saponins from leaves of Acanthopanax sessiliflorus and their inhibitory activity on pancreatic lipase. J Agric Food Chem. 2006;54(2):335-41

Zareen S, Choudhary MI, Akhtar MN, Khan SN. $\alpha$-Glucosidase inhibitory activity of triterpenoids from Cichorium intybus. J Nat Prod. 2008;71(5):910-3.

Zhang YN, Zhang W, Hong D, Shi L, Shen Q, Li JY, et al. Oleanolic acid and its derivatives: new inhibitor of protein tyrosine phosphatase 1B with cellular activities. Bioorg. Med. Chem. 2008;16(18):8697-8705.

Received for publication on $04^{\text {th }}$ April 2017 Accepted for publication on $17^{\text {th }}$ July 2017 